\title{
Keberhasilan Program Tahfidz Al-Qur'an Kejar Paket B Darul Qur'an Al-Karim Baturraden Banyumas T.A 2018-2019
}

\author{
Safrudin Aziz ${ }^{1}$ \\ ${ }^{1}$ Institut Agama Islam Negeri Purwokerto \\ azieez@iainpurwokerto.ac.id.
}

\begin{abstract}
Keywords:
tahfidz al-Qur'an;

pursue package $\mathrm{B}$;

non formal

education.

\begin{tabular}{l}
\hline \hline \\
\hline Keywords: \\
tahfidz al-Qur'an; \\
pursue package B; \\
non formal \\
education.
\end{tabular}

Abstract

The study entitled The Success of the Tahfidz al-Qur'an Program on the Pursuit of Package B Daqu al-Karim Banyumas Baturraden is motivated by several things including: First, Tahfidz 30 juz program of the Pursuit of Package B Daqu alKarim is the only flagship program in Banyumas Regency. Second, the success rate of the Tahfidz program reaches $82 \%$. Thirdly, Daqu al-Karim's Tahfidz Package B program has an applicative curriculum that is arranged in a planned, measurable manner and takes into account the environment, culture, and conditions of the child. Data collection in this study using the method of observation, interviews and documentation. The data analysis is done through the process of data reduction, data display and drawing conclusions and verification.

The results of this study indicate the success of the Tahfidz alQur'an program on the Pursuit of Package B Daqu al-Karim in the 2018-2019 school year was determined by the institution's vision policy and strengthening strategies implemented in the program: first, prepare the tahfidz curriculum applicatively. Second, tighten the selection of recruitment of teaching staff and prospective students. Third, strengthen the development of learning methods. Fourth, improve leadership quality. Fifth, create cooperation and agreement to approve the program. As well as the sixth, implementing program evaluation and control. The six strategies are synergized with each other and the implementation is evaluated based on the target targets that have been determined.
\end{abstract}

Kata Kunci:

tahfidz al-Qur'an; kejar

paket $\mathrm{B}$; pendidikan non formal.
Abstrak:

Penelitian berjudul Keberhasilan Program Tahfidz al-Qur'an pada Kejar Paket B Daqu al-Karim Baturraden Banyumas dilatarbelakangi oleh beberapa hal diantaranya: pertama, 
program tahfidz 30 juz Kejar Paket B Daqu al-Karim sebagai satu-satunya program unggulan yang ada di Kabupaten Banyumas. Kedua, tingkat keberhasilan program tahfidz mencapai $82 \%$. Ketiga, program tahfidz Kejar Paket B Daqu alKarim memiliki kurikulum aplikatif yang disusun secara terencana, terukur serta memperhatikan aspek lingkungan, budaya, serta kondisi anak. Penggalian data dalam penelitian ini menggunakan metode observasi, wawancara dan dokumentasi. Adapun analisa data dilakukan melalui proses reduksi data, display data serta penarikan kesimpulan dan verifikasi.

Hasil penelitian ini menunjukan Keberhasilan program tahfidz al-Qur'an pada Kejar Paket B Daqu al-Karim tahun ajaran 20182019 ditentukan oleh kebijakan visi lembaga serta penguatan strategi yang terimplementasi dalam program: pertama, mempersiapkan kurikulum tahfidz secara aplikatif. Kedua, memperketat seleksi terhadap rekruitmen tenaga pendidik serta calon peserta didik. Ketiga, memperkuat pengembangan metode pembelaran. Keempat, meningkatkan mutu kepemimpinan. Kelima, menciptakan kerjasama dan kesepakatan menyetujui program. Serta keenam, menerapkan evaluasi dan kontrol program. Keenam strategi tersebut saling bersinergi satu sama lain dan pelaksanaanya terevaluasi berdasarkan target capaian yang telah di tentukan.

\begin{tabular}{cc}
\hline \hline Received : 22 Februari 2019; Revised: 25 Februari 2019; Accepted: 8 Desember 2019 \\
\hline $\begin{array}{c}\text { ( Tadris Jurnal Pendidikan Islam } \\
\text { Institut Agama Islam Negeri Madura, Indonesia }\end{array}$ & This is an open access article under the CC-BY-NC license \\
\hline \hline
\end{tabular}

\section{Pendahuluan}

Program pendidikan non formal berbentuk kejar paket hingga kini masih dipandang sebelah mata. Anggapan miring kerap terlontarkan bahwa kejar paket lebih diperuntukan bagi anak miskin, terbelakang, bodoh, malas bersekolah, dan sejenisnya. Mengenyam pendidikan di kejar paket dianggap sebagai anak yang tidak memiliki banyak waktu serta tidak mampu mengikuti proses pembelajaran secara formal. Sehingga proses pembelajaran kejar paket kerap dilakukan diwaktu sore atau malam hari.

Begitu pula dengan asesoris yang mereka pergunakan. Peserta didik tidak wajib berseragam, tidak harus bersepatu, tidak perlu berjas, bertopi dan berdasi layaknya asesoris di sekolah formal pada umumnya. Dalam bidang prestasi, sangat jarang terdengar peserta didiknya meraih prestasi nasional terlebih internasional. Umumnya program kejar paket tidak memiliki kekhasan terhadap kompetensi lulusan yang diunggulkan. Perihal tersebut berdampak sebagian besar masyarakat masih menganggap Kejar Paket sebagai program pendidikan second class.

Tuntutan merancang sistem pendidikan unggulan pada Kejar Paket mutlak menjadi satu keniscayaan. Lulusan Kejar Paket idealnya memiliki kompetensi secara berkualitas, menguasai seperangkat pengalaman dan keterampilan (life skills) sebagaimana dimiliki oleh Kejar Paket B Daqu al-Karim Baturraden Banyumas. 
Kejar Paket B Daqu al-Karim Baturraden Banyumas, selanjutnya disebut Kejar Paket B Daqu al-Karim secara kelembagaan berada di bawah pengelolaan PKBM Darul Qur'an al-Karim Karangtengah Baturraden Banyumas. Kejar Paket B ini secara resmi berdiri semenjak tahun 2017 melalui Surat Keputusan Dinas Kabupaten Banyumas nomor: 421.9 / 711 / 2017. ${ }^{1}$ Kejar Paket B ini memiliki visi: Qur'ani, unggul, peduli dalam mensukseskan pendidikan nasional tahun 2030.

Guna mensukseskan visi tersebut, Kejar Paket B Daqu al-Karim memiliki satu program unggulan berupa tahfidz al-Qur'an 30 juz. Dengan mempertimbangkan aspek filosofis, psikologis, sosial budaya serta ilmu pengetahuan dan teknologi, Kejar Paket B Daqu al-Karim merealisasikan kurikulum Nasional (Kurtilas), muatan lokal serta menggagas kurikulum Tahfidz al-Qur'an sebagai program unggulan serta menjadi kekhasan yang tidak dimiliki oleh lembaga Kejar Paket yang lain. ${ }^{2}$

Dalam merealisasikan program tersebut, Kejar Paket B Daqu al-Karim memiliki strategi secara khusus di samping dukungan material, intelektual, emosional maupun spiritual. Selaras dengan ungkapan Dakir, ${ }^{3}$ rumusan program pendidikan harus melibatkan aspek cipta (otak, kecerdasan), rasa (hati, susila, keindahan) dan karsa (sumber kemauan) sehingga kesatuan aspek tersebut melahirkan manusia yang harmonis yang dicirikan dalam sembilan $\mathrm{K}$ yakni: ketaqwaan, kecerdasan, kesusilaan, kejujuran, kekreatifan, kesehatan, keterampilan, kemasyarakatan, serta kemandirian.

Melihat uraian di atas, rumusan masalah dalam tulisan ini adalah strategi apa yang dikembangkan Kejar Paket B Daqu al-Karim dalam mensukseskan program tahfidz al-Qur'an tahun ajaran 2018/2019?. Adapun tujuan penelitian ini adalah mengetahui capaian target serta strategi keberhasilan program tahfidz alQur'an pada Kejar Paket B Daqu al-Karim T.A. 2018-2019.

\section{Pengelolaan Mutu Pendidikan Berbasis Tahfidzul Qur'an}

a. Pengelolaan Mutu Pendidikan

Masyarakat milenial saat ini terbilang lebih cerdas dalam memilih lembaga pendidikan yang bermutu tanpa memperhatikan besarnya biaya serta doktrindoktrin tertentu. Bahkan sebagian masyarakat sudah mampu menilai suatu lembaga pendidikan yang bermutu harus dibuktikan dengan produk atau out put lulusan yang berkualitas serta kejelasan program pendidikan yang mampu mengembangkan potensi intelektual, emosional, spiritual serta keterampilan anak didiknya. ${ }^{4}$

Mutu pendidikan secara umum dapat dicapai melalui dua faktor yakni input dan manajemen. Faktor input mencakup aspek kurikulum, perencanaan dan evaluasi, ketenagaan, kesiswaan, sarana dan fasilitas, iklim sekolah, serta hubungan sekolah dengan masyarakat. Sedangkan faktor yang menekankan pada aspek manajemen meliputi: proses pengelolaan program, proses pengambilan keputusan, proses pembelajaran, dan proses monitoring evaluasi. ${ }^{5}$

Adapun pengelolaan program pendidikan Kejar Paket dapat dilakukan melalui pendekatan Total Quality Management (TQM). Melalui TQM, pengelola harus mampu menyusun perencanaan, pendeteksian, pengukuran, penilaian

\footnotetext{
${ }^{1}$ Dokumen PKBM Darul Qur'an al-Karim Karangtengah Baturraden Banyumas Tahun 2017.

2 Dokumen Kurikulum Kejar Paket B Daqu al-Karim Karangtengah Baturraden Banyumas tahun 2017.

${ }^{3}$ Dakir, Perencanaan dan Pengembangan Kurikulum (Jakarta: Rineka Cipta, 2004), hlm. 27-28.

4 Imam Suprayogo, Quo Vadis Madrasah, Gagasan, Aksi dan Solusi Pembangunan Madrasah (Yogyakarta: Hikayat, 2007), hal. 55-56.

5 Departemen Pendidikan Nasional, Manajemen Peningkatan Mutu Berbasis Sekolah, Konsep Dasar, Buku 1 (Jakarta: Direktorat Jenderal Pendidikan Dasar dan Menengah, 2002), hal. 22-25.
} 
terhadap SDM, kegiatan serta proses dan hasil pembelajaran. Bahkan untuk menjamin tujuan mutu, semua aspek di atas harus diset dalam perencanaan secara matang serta dipenuhi dalam proses penyelenggaraan layanan pendidikan. ${ }^{6}$

Secara operasional implementasi TQM untuk Kejar Paket dilakukan melalui: pertama, improvisasi berkelanjutan, artinya pihak manajemen selalu melakukan perbaikan dan peningkatan secara terus menerus untuk menjamin dan mendukung peningkatan kualitas yang diharapkan. Kedua, pengelola menentukan standar-standar kualitas yang harus dipertahankan dan ditingkatkan bagi terwujudnya kualitas pendidikan, proses pembelajaran, kurikulum, metode, dan evaluasi. Ketiga, pengelola membangun kultur organisasi yang menghargai kualitas. Keempat, pengelola berkemampuan membangun kesinambungan organisasi terhadap perkembangan dan kebutuhan zaman dengan banyak melakukan perubahan dan pengawasan. Kelima, pengelola mampu membangun public relation secara harmonis dan dinamis. ${ }^{7}$

Melengkapi uraian di atas, program Kejar Paket yang unggulan diperlukan langkah diantaranya: pertama, menyamakan komitmen mutu secara total bagi pengelola, tutor, peserta didik serta stakeholder. Kedua, mengusahakan adanya program peningkatan mutu pendidikan di lembaga pendidikan yang bersangkutan. Ketiga, meningkatkan kualitas pelayanan administrasi pendidikan. Keempat, kepemimpinan yang efektif. Kelima, terdapat standar mutu lulusan. Keenam, memperkuat jaringan kerja sama secara luas. Ketujuh, penataan organisasi yang baik (tata kerja) dan kedelapan, menciptakan iklim dan budaya yang kondusif.

Melalui upaya tersebut produk pendidikan Kejar Paket diharapkan mampu menciptakan lulusan yang berkualitas sebagai upaya konkret melakukan perubahan mendasar pada peningkatan kualitas sumber daya manusia (SDM) Indonesia. Sebab sistem pendidikan yang terfokus pada upaya menciptakan lulusan berkualitas, akan mendorong tumbuhnya berbagai karakter SDM yang positif seperti disiplin, jujur dan lebih mengandalkan kemampuan sendiri, pola pikir yang lebih logis dan ilmiah serta terbiasa bekerja keras, dan tahan mental dalam menghadapi kesulitan. ${ }^{9}$

\section{b. Tahfidz al-Qur'an Sebagai Program Unggulan}

Pendidikan berkualitas selain menekankan aspek mutu input, proses, dan out put, juga ditunjukan melalui kekhasan program yang dimiliki. Tahfidz alQur'an saat ini kerap dipilih sebagai program unggulan dibeberapa lembaga pendidikan di Indonesia. Meskipun tidak setiap lembaga pendidikan mampu menerapkan program ini secara total dan sempurna, tahfidz al-Qur'an kerap dijadikan sebagai program populer berbiaya mahal. Program tersebut mampu menarik minat masyarakat secara luas. Karena diyakini sumber pendidikan karakter terlengkap berasal dari al-Qur'an.

Keberhasilan tahfidz al-Qur'an sebagai salah satu program unggulan memerlukan berbagai kesiapan diantaranya kurikulum serta berbagai pendekatan khusus yang disusun secara serius untuk mencapai program yang

\footnotetext{
${ }^{6}$ Safrudin Aziz, Manajemen Mutu Perguruan Tinggi: Koreksi dan Implementasi (Yogyakarta: Gava Media, 2016), hal. 19-20.

7 M. Dachnel Kamars, “Kebijakan Pendidikan dan Peningkatan Mutu Pendidikan”, dalam Membangun Paradigma Pendidikan Islam, ed. Muhmidayeli (Riau: Program Pascasarjana UIN Suska Riau, 2007), hal.. 62.

${ }^{8}$ Syafaruddin, Manajemen Lembaga Pendidikan Islam (Jakarta: Ciputat Press, 2005), hal. 290.

${ }^{9}$ Sutrisno \& Suyatno, Pendidikan Islam di Era Peradaban Modern (Jakarta: Prenadamedia Group, 2015), hal. 64.
} 
direncanakan. Selain itu, memahami kondisi peserta didik melalui interaksi, penyediaan fasilitas dan sarana prasarana yang mendukung kegiatan pendidikan, menciptakan iklim yang harmonis dan kondusif, dukungan serta pelibatan orang tua dan masyarakat dalam merealisasikan program pendidikan, serta sikap guru sebagai figur, motivator, serta pendidik menjadi satu hal yang harus dipersiapkan. Semua itu harus diupayakan agar program tahfidz al-Qur'an dapat terealisasi sesuai dengan target yang telah ditetapkan. Terlebih menghafal al-Qur'an terkategori sebagai proses belajar yang berat serta memerlukan waktu dan ketekunan secara serius.

Menghafal al-Qur'an memerlukan kesejahteraan psikologis yakni kondisi di mana seseorang mampu menerima kondisi dirinya, mampu membentuk hubungan yang hangat dengan orang lain, mampu mengontrol lingkungan, memiliki kemandirian, memiliki tujuan dan makna dalam hidup, mampu mengembangkan bakat serta kemampuan untuk perkembangan pribadi. ${ }^{10}$

Dari uraian di atas dapat disimpulkan bahwa merealisasikan tahfidz alQur'an sebagai program unggulan memerlukan pengelolaan secara serius serta dukungan dan kerjasama dari berbagai pihak. Sebab sebagus apapun program pendidikan yang sudah digagas, tidak akan mencapai target keberhasilan tanpa di dukung oleh berbagai aspek pendukung lainnya.

\section{Keberhasilan Program Tahfidz al-Qur'an Kejar Paket B Daqu Al-Karim}

Tahfidz al-Qur'an merupakan program unggulan yang kembangkan oleh Kejar Paket B Daqu Al-Karim semenjak tahun ajaran 2016/2017. Kurikulum program ini bertujuan mengembangkan potensi peserta didik dalam menghafal al-Qur'an 30 Juz yang ditempuh selama 6 semester. Sehingga input peserta didik berasal dari anak-anak cerdas yang sudah berkemampuan membaca al-Qur'an secara tartil serta menguasai hafalan Juz'amma (Juz 30).

Program tahfidz al-Qur'an pada Kejar Paket B Daqu al-Karim memiliki kurikulum yang sangat fleksibel. Artinya target hafalan awalnya disesuaikan dengan kondisi kemampuan anak melalui strategi tiqror. Namun semakin bertambahnya waktu target hafalan secara dinamis semakin meningkat dari satu lembar hingga lima lembar al-Qur'an. Sehingga implementasi hafalan ditempuh dalam capaian sebagai berikut:

\begin{tabular}{|c|c|c|c|c|c|c|}
\hline \multirow{2}{*}{$\begin{array}{l}\text { Kelas } \\
\text { Semester }\end{array}$} & \multicolumn{2}{|c|}{ VII } & \multicolumn{2}{|c|}{ VIII } & \multicolumn{2}{|c|}{ IX } \\
\hline & Gasal & Genap & Gasal & Genap & Gasal & Genap \\
\hline $\begin{array}{l}\text { Juz ke- ...s/d... } \\
\text { Penguasaan }\end{array}$ & $30-27$ & $26-22$ & $21-16$ & $15-9$ & $8-1$ & 30 \\
\hline $\begin{array}{l}\text { Jumlah Juz per } \\
\text { Semester }\end{array}$ & 4 & 5 & 6 & 7 & 8 & 30 \\
\hline $\begin{array}{l}\text { Perolehan Jumlah } \\
\text { Juz per Tahun }\end{array}$ & \multicolumn{2}{|c|}{9} & \multicolumn{2}{|c|}{13} & 8 & 30 \\
\hline
\end{tabular}

(Tabulasi 1. Rata-Rata Penguasaan Hafalan Peserta Didik)

Dari schedule implementasi program tahfidz di atas tampak kenaikan semester menunjukan tingkat penguasaan hafalan peserta didik semakin meningkat. Perihal tersebut disebabkan pembelajaran tahfidz menggunakan pendekatan proses, yakni anak secara langsung mengalami dalam menghafal serta menyetorkan hafalan yang telah dikuasainya secara langsung kepada

\footnotetext{
${ }^{10}$ Yoga Achmad Ramadhan, "Kesejahteraan Psikologis pada Remaja Santri Penghafal al-Qur'an”, Jurnal Psikologika, (Vol. 17, No. 1, 2012), hal. 33.
} 
guru. Proses mengalami melahirkan seperangkat pengalaman bagi anak untuk dapat mencapai atau melampaui target hafalan. Melalui proses mengalami pembelajaran tahfidz akan menjadi bagian integral dari diri setiap peserta didik. Bukan lagi potongan-potongan pengalaman seseorang yang disodorkan kepada peserta didik untuk diterima. Sehingga proses mengalami secara langsung mampu mengantarkan peserta didik untuk mengejawantahkan materi serta proses pembelajaran yang telah dialaminya. ${ }^{11}$

Adapun rerata penguasaan menghafal al-Qur'an pada peserta didik angkatan tahun ajaran 2016/2017 sejumlah 11 anak tercapai kurang dari 2,5 tahun dengan perincian sebagai berikut:

\begin{tabular}{cccccc}
\hline No & $\begin{array}{c}\text { Nama } \\
\text { Siswa }\end{array}$ & Hari & $\begin{array}{c}\text { Waktu } \\
\text { Tahun }\end{array}$ & $\begin{array}{c}\text { Jumlah } \\
\text { Hafalan }\end{array}$ & Prestasi \\
\hline 1 & x1 & 690 & 1 tahun 325 Hari & 30 Juz & Memuaskan \\
2 & x2 & 760 & 2 tahun 30 Hari & 30 Juz & Memuaskan \\
3 & x3 & 769 & 2 tahun 39 Hari & 30 Juz & Memuaskan \\
4 & x4 & 778 & 2 Tahun 48 Hari & 30 Juz & Memuaskan \\
5 & x5 & 780 & 2 Tahun 50 Hari & 30 Juz & Memuaskan \\
6 & x6 & 801 & 2 Tahun 71 Hari & 30 Juz & Memuaskan \\
7 & x7 & 820 & 2 Tahun 90 Hari & 30 Juz & Memuaskan \\
8 & x8 & 821 & 2 Tahun 91 Hari & 30 Juz & Memuaskan \\
9 & x9 & 855 & 2 Tahun 125 Hari & 30 Juz & Memuaskan \\
10 & x10 & 913 & 2,5 Tahun & 15 Juz & Target tidak \\
& & & & tercapai \\
11 & x11 & 913 & 2,5 Tahun & 14 Juz & Target tidak \\
\end{tabular}

(Tabulasi 2. Ketercapaian Program Tahfidz Angkatan T.A. 2016-2017)

Tabulasi di atas menunjukan program tahfidz al-Qur'an pada Kejar Paket B Daqu al-Karim Baturraden Banyumas angakat tahun ajaran 20162017 menunjukan tingkat ketercapaian 82\%. Ketercapaian target tersebut dipengaruhi oleh kondisi fisik, penciptaan iklim pembelajaran yang mendukung, kualitas input calon peserta didik serta kemandirian anak dalam menghafal al-Qur'an. Sementara 18\% (dua orang peserta didik) mengalami kegagalan dikarenakan kondisi peserta didik kerap mengalami gangguan fisik (sakit).

\section{Strategi Keberhasilan Program Tahfidzul Qur'an Kejar Paket B Daqu al- Karim}

a. Mempersiapkan Kurikulum Tahfidz Al-Qur'an

Kurikulum tidak sebatas dipahami sebagai sejumlah mata pelajaran yang dipersiapkan guna mencapai tujuan pendidikan tertentu saja. Namun kurikulum hendaknya berisi seluruh kegiatan yang disusun secara terprogram serta dilaksanakan oleh organisasi sekolah melalui proses perencanaan yang matang. Selain itu, kurikulum juga diartikan sebagai semua pengalaman, aktivitas-aktivitas, suasana dan pengaruh-pengaruh yang diberikan kepada peserta didik di bawah pengelolaan sekolah. ${ }^{12}$

\footnotetext{
11 Safrudin Aziz, Strategi Pembelajaran Aktif Anak Usia Dini: Panduan bagi Guru, Orang Tua, Konselor, dan Praktisi Pendidikan Anak Usia Dini (Yogyakarta: Kalimedia, 2017), hal. 120.

${ }^{12}$ Omar Mohammad al-Taumy al-Syaibany, Falsafah Pendidikan Islam, terj. Hasan Langgulung
} 
Kurikulum tahfidz Kejar Paket B Daqu al-Karim secara khusus dirancang secara mandiri oleh tim ahli semenjak tahun ajaran 2015-2016. Secara teknis, isi kurikulum Tahfidz meliputi empat tahapan yakni: pertama, calon peserta didik dipersyaratkan sudah menguasai hafalan juz'amma. Jika calon peserta didik belum menguasainya diwajibkan masuk kelas persiapan maksimal selama 1 semester. Pasca lulus dari kelas persiapan, calon peserta didik diperbolehkan mengikuti program Tahfidz.

Kedua, pembagian target hafalan terklasifikasi atas tiga tahapan yakni: kelas VII berkewajiban menghafal 9 juz (juz 30-22), kelas VIII berkewajiban menghafal 13 juz (juz 21-9), sementara di kelas IX siswa wajib menghafal sebanyak 8 juz (juz 8-1).

Ketiga, struktur kurikulum Tahfidz disajikan dalam alokasi waktu istimewa. Waktu menghafal serta menyetorkan hafalan terbagi atas waktu pagi yakni pukul: 07.00-11.00, waktu sore yakni pukul: 16.00-17.30, waktu malam yakni pukul: 18.30-21.00. Ploting waktu menghafal memiliki porsi lebih panjang dibandingkan dengan aktivitas pembelajaran lainnya. Perihal tersebut menjadi satu bentuk kekhasan kurikulum Tahfidz yang dimiliki oleh Kejar Paket B Daqu al-Karim. Adapun kondisi otak dan fisik peserta didik di pagi hari terbilang masih segar dan bergairah. Sehingga waktu pagi dipilih sebagai waktu ideal menyampaikan setoran hafalan. Selain alokasi waktu di atas, peserta didik juga masih diberikan tugas menjalankan shalat tahajud berjama'ah pada pukul 02.30-03.00 WIB.

Keempat, kurikulum Tahfidz menerapkan sistem evaluasi secara ketat. Evaluasi ini meliputi aspek kualitas bacaan dan hafalan dari setiap guru tahfidz. Hasil evaluasi menunjukan 82\% siswa angkatan 2016/2017 mampu menguasai hafalan al-Qur'an kurang dari 2,5 tahun. Kelima, kurikulum Tahfidz di susun dalam program boarding school. Artinya meskipun sistem pendidikannya berbentuk Kejar Paket B namun model pembelajaran tahfidz dilakukan sepanjang hari di asrama. Sehingga peserta didik bisa menghafal al-Qur'an serta mempelajari ilmu pengetahuan lainnya dengan konsentrasi secara serius.

Langkah di atas merupakan satu bentuk terobosan mengemas mutu pendidikan tahfidz melalui pendekatan TQM dengan menentukan standarstandar kualitas. Dalam konteks ini, pengelola Kejar Paket B Daqu al-Karim tampaknya sudah menyadari bahwa standar kualitas harus direncanakan, di susun, dipertahankan, ditingkatkan melalui upaya perbaikan secara terus menerus sehingga tercipta out put pendidikan yang berkulitas. Terlebih keberhasilan program tahfidz memberikan peluang kepada peserta didik untuk memperoleh beasiswa hingga perguruan tinggi, di samping memiliki karakter yang mulia dalam kehidupannya.

Gagasan kurikulum Tahfidz nampaknya selaras dengan pendapat McNeil bahwa kurikulum pendidikan selain berisi seperangkat pengalaman, aktivitas dan suasana pembelajaran juga harus memuat beberapa aspek pertimbangan diantaranya kurikulum harus mampu memberikan kepuasan kepada setiap individu serta dapat memenuhi kebutuhan bagi pertumbuhan dan integritas pribadi sekaligus kurikulum harus diarahkan pada kebutuhan individu dan masyarakat, khususnya terkait dalam menciptakan masa depan masyarakat yang lebih baik. ${ }^{13}$

(Jakarta: Bulan Bintang, 1979), hlm. 483.

${ }_{3}$ Mulyadi, Kepemimpinan Kepala Madrasah dalam Mengembangkan Budaya Mutu: Studi Kasus di Madrasah Terpadu MAN 3 Malang, MAN Malang 1 dan MA Hidayatul Mubtadi'in Kota Malang (Jakarta: Badan Litbang dan Diklat Kementerian Agama RI, 2010), hal. 219-220. 
Dengan demikian, kurikulum Tahfidz sebagai kekhasan yang digagas oleh Kejar Paket B Daqu al-Karim memiliki tujuan ganda yakni mencerdaskan otak anak melalui al-Qur'an sekaligus menanamkan karakter yang baik sesuai dengan nilai-nilai akhlak dalam al-Qur'an. Sehingga desain kurikulum Tahfidz mengantarkan anak didik untuk memiliki kecerdasan secara intelektual, emosional, sosial sekaligus spiritual.

b. Memperketat Rekrutmen Guru al-Qur'an dan Peserta Didik

Rekrutmen guru dan peserta didik pada Kejar Paket B Daqu al-Karim dilakukan secara selektif sesuai dengan standar yang telah ditetapkan. Sistem rekrutmen guru dilakukan melalui proses terencana, terseleksi dan terlaporkan. Tiga tahap seleksi dalam perekrutan guru al-Qur'an meliputi: pertama, seleksi administrasi mencakup: IPK < 3.0, menunjukan syahadah hafidz asli dari lembaga terpercaya, serta kelengkapan syarat administrasi lain pada umumnya. Kedua, ujian tertulis sesuai dengan kompetensi bidang serta Test Potensi Akademik (TPA) atau test psikologi. Ketiga, wawancara serta lulus seleksi hafalan al-Qur'an.

Hasil proses seleksi dipublikasikan melalui media sosial ataupun papan pengumuman. Semua calon guru al-Qur'an wajib menandatangani kontrak kerja sekaligus berhak menerima SK pengangkatan sebagai guru tetap yayasan atau guru kontrak. Pasca pengangkatan, setiap calon guru diwajibkan mengikuti program pelatihan peningkatan kompetensi serta profesionalisme calon pendidik. Setelah menjadi guru, pihak yayasan mengirimkan setiap SDM nya untuk magang atau mengikuti bimbingan teknis pada lembaga pendidikan lain.

Berbagai upaya di atas bertujuan mempersiapkan mutu SDM guru yang profesional, progresif, kompetitif serta berkarakter kuat dan mulia. Sebab tenaga pendidik yang cakap memiliki pengaruh kuat dalam meningkatkan prestasi belajar siswa dan lebih baik pengaruhnya dalam meningkatkan prestasi belajar dibandingkan dengan pengajar dalam sistem tradisional. ${ }^{14} \mathrm{Hal}$ tersebut terbukti $82 \%$ angkatan pertama mampu menguasai hafalan al-Qur'an secara total dalam waktu kurang dari 2,5 tahun.

Dengan demikian semakin ketat seleksi masuk yang diterapkan, semakin menjamin output lulusan memiliki kualitas yang telah ditetapkan. Sehingga sistem rekrutmen guru al-Qur'an secara ketat bertujuan menciptakan sistem pendidikan yang berkualitas serta komitmen dalam mengembangkan kekhasan sebagai lembaga pendidikan pencetak para penghafal al-Qur'an, memiliki akhlak mulia, cerdas dan peduli sebagai bekal meneruskan pendidikan ke jenjang yang lebih tinggi dan berdaya saing.

Adapun seleksi calon peserta didik menitikberatkan pada penguasaan hafalan juz 'amma. Hasil seleksi diklasifikasikan menjadi tiga jenis yakni calon peserta didik dengan kriteria hafal unggulan (juz 30) secara langsung diterima sebagai peserta didik. Sementara kriteria minimal (hafal setengah dari juz 30) di terima dalam kelas persiapan. Sedangkan calon peserta didik dengan status belum bisa membaca al-Qur'an dinyatakan gugur dalam seleksi.

Pembagian standar ini dimaksudkan memberikan kesempatan kepada calon peserta didik yang belum menguasai hafalan juz 'amma secara sempurna. Adapun calon peserta didik yang belum bisa membaca terlebih memiliki hafalan juz 'amma dengan baik diberikan kesempatan untuk

\footnotetext{
${ }^{14}$ Muntasir, M. Saleh, Pengajaran Terprogram, Teknologi Pendidikan dengan Pengandalan Tutor (Jakarta: Rajawali, 1985), hal. 3.
} 
mengembangkan bakat, minat serta potensi lain yang dimilikinya. Sebab calon peserta didik tersebut terbilang tidak memiliki bakat serta minat mengikuti program tahfidz secara serius.

Sementara kriteria calon peserta didik yang telah menguasai hafalan juz 'amma menjadi tolok ukur input sesuai standar. Sebab peserta didik yang sudah menguasai hafalan juz 'amma sangat dimungkinan lebih cepat menjalani proses menghafal secara total sesuai target waktu yang telah ditetapkan. Hal tersebut selaras dengan teori raw input production bahwa raw input peserta didik sangat berpeluang meraih prestasi belajar yang baik. ${ }^{15}$

c. Pengembangan Metode Pembelajaran

Selain menekankan pada kualitas input, strategi keberhasilan program tahfidz juga didukung oleh proses pembelajaran yang serius dan menyenangkan. Dua hal ini diyakini sebagai aktualisasi merealisasikan program pendidikan tahfidz yang unggul dan berkualitas. Dalam proses pembelajaran tahfidz, guru menerapkan metode quantum learning yang menekankan proses pembelajaran harus berlangsung secara menyenangkan (learning is fun).

Pembelajaran tahfidz secara menyenangkan dilakukan diberbagai tempat bahkan terkadang menginterkoneksikan ayat al-Qur'an dengan lingkungan alam sekitar, ilmu pengetahuan sains dan teknologi. Program pembelajaran tahfidz tidak mendikotomisasikan al-Qur'an dengan ilmu-ilmu yang lain. Sebab sikap mendikotomisasikan ilmu pengetahuan, saintek dengan al-Qur'an mengakibatkan nilai-nilai ketuhanan tercerabut. Sehingga sikap dikotomi kerap melahirkan ilmuwan kafir yang mengingkari adanya kekuasaan Tuhan.

Kejar Paket B Daqu al-Karim tampaknya memiliki inovasi khusus dalam mengintegrasikan serta menginterkoneksikan antara nilai-nilai al-Qur'an dengan ilmu pengetahuan. Sehingga metode integratif interkonektif ini mampu memadukan substansi ilmu pengetahuan dengan nilai-nilai al-Qur'an yang di dalamnya memuat nilai-nilai keimanan, ketuhanan, ketauhidan, akhlak, dan sebagainya. Dengan demikian inovasi dalam mengembangkan metode integratif-interkonektif berimplikasi pada penanaman nilai-nilai al-Qur'an dalam diri setiap peserta didik. Sehingga guru dengan peserta didik memahami dan menyadari bahwa ilmu pengetahuan serta sains dan teknologi tidak terpisah dari nilai transendental.

Secara aplikatif pembelajaran tahfidz dilakukan melalui student active learning yang menempatkan peserta didik tidak sebagai objek namun sebagai subjek pembelajaran. Proses pembelajaran diawali dengan membaca Ummul Kitab sebagai bentuk permohonan agar peserta didik senantiasa diberikan kemudahan serta keberhasilan dalam menghafal. Setelah itu, peserta didik menyiapkan hafalan masing-masing dengan target sehari semalam sebanyak 2-3 halaman. Setelah menguasai hafalan 2-3 halaman, tahap berikutnya melakukan setoran hafalan ke kawannya minimal tiga kali sebelum ia menyetorkan hafalan ke gurunya.

Strategi lain yang dipergunakan oleh guru diantaranya menugaskan peserta didik untuk memperbanyak membaca al-Qur'an minimal 10 juz dalam sehari. Perihal tersebut bertujuan memperlancar bacaan, lebih mengenal kata, kalimat, ayat, surat serta latihan duduk yang lama. Selain itu, guru dalam

15 Halfian Lubis, Pertumbuhan SMA Islam Unggulan di Indonesia: Studi Tentang Strategi Peningkatan Kualitas Pendidikan (Jakarta: Badan Litbang dan Diklat Departemen Agama RI, 2008), hal. 27. 
merealisasikan proses pembelajaran selalu memberikan motivasi serta evaluasi terhadap peserta didik. Jumlah setoran atau tugas menghafal juga diberikan guru secara tertulis kepada setiap peserta didiknya.

Aktualisasi proses pembelajaran di atas menuntut setiap peserta didik bersikap aktif, mandiri, serta bertanggung jawab dalam menghafal serta menyetorkan hafalan sesuai dengan catatan yang telah ditugaskan. Proses tersebut menjadikan setiap peserta didik terlibat aktif dalam menghafal dan menyetorkan hafalan yang diperolehnya, memahami harapan guru, mengetahui hasil belajar yang telah dilakukannya, dapat belajar dari pengalamannya sendiri atau orang lain, memiliki peluang serta kesempatan yang sama untuk berhasil dan melakukan sesuatu, serta memperoleh penjelasan dari guru dengan berbagai variasi metode dan teknik yang sudah diterapkannya. ${ }^{16}$ Model belajar berbasis study tour dan outbond kerap dilakukan dalam rangka mengkombinasi model pembelajaran tahfidz serta menambah pengalaman peserta didik untuk mengenal dunia penerbitan, transportasi, alam terbuka dan sejenisnya.

Dengan demikian proses pembelajaran tahfidz Kejar Paket B Daqu alKarim bersifat interaktif dan menyenangkan. Proses pembelajaran tersebut tidak lepas dari perencanaan hingga evaluasi secara serius guna menciptakan out put pendidikan berkualitas dan bermakna.

d. Peningkatan Mutu Kepemimpinan

Strategi keberhasilan program tahfidz Kejar Paket B Daqu al-Karim juga ditentukan oleh aspek kepemimpinan yang bermutu. Kepemimpinan tidak sebatas pada penanggung jawab teknis (kepala program), namun ketua PKBM Darul Qur'an al-Karim yang membawahi program Kejar Paket B kerap melakukan terobosan progresif serta kebijakan dan inovasi dalam mensukseskan program tahfidz.

Pemegang kepemimpinan berupaya mengartikulasikan visi dan misi program Kejar Paket B kepada semua guru, tenaga kependidikan, orang tua serta peserta didik. Kekuatan visi dan misi Kejar Paket B adalah untuk meningkatkan semangat serta sebagai sumber inspirasi bagi semua guru dan pengelola untuk meningkatkan kinerja dan motivasi kerja secara profesional. Artinya visi dan misi dapat mengarahkan moralitas semua unsur untuk meningkatkan mutu pendidikan. Semua itu dilakukan agar semua komponen mempunyai rasa memiliki dan bertanggung jawab terhadap visi dan misi yang sudah ditetapkan. ${ }^{17}$ Sehingga kesuksesan program unggulan tahfidz bukan sebatas isapan jempol, namun sebuah kenyataan yang dapat dipertanggung jawabkan kepada masyarakat luas.

e. Menciptakan Kerjasama dan Kesepakatan Program

Kesuksesan program tahfidz Kejar Paket B Daqu al-Karim dapat terealisasi dengan baik atas kerjasama serta kesepakatan antara pihak pengelola program dengan orang tua siswa. Artinya di awal masa orientasi, orang tua sudah diberikan pemahaman tentang program tersebut sekaligus dukungan orang tua secara utuh dalam mensukseskan anak-anaknya menguasai hafalan al-Qur'an. Setiap orang tua tidak sekedar mencukupi kebutuhan secara material. Tetapi setiap orang tua diberikan tugas oleh pengelola lembaga untuk selalu memotivasi anak yang sedang berjuang

\footnotetext{
${ }^{16}$ Chaidar, "Metodologi Pembelajaran", Makalah seminar sehari pada Perguruan al-Azhar Medan, tahun 2005.

${ }^{17}$ Mulyadi, Kepemimpinan Kepala Madrasah., hal. 303.
} 
menghafalkan al-Qur'an, mendoakan anak melalui wasilah melaksanakan puasa sunah, shalat tahajud dan hajat agar cita-cita anak-anak mereka menjadi seorang hafidz berhasil secara sempurna.

Kesepakatan di atas dilakukan secara sadar serta tidak terdapat paksaan sedikit pun dari berbagai pihak. Bahkan orang tua diberikan pemahaman secara komprehensif oleh pihak pengelola bahwa seseorang yang menghafalkan al-Qur'an tidak akan menderita stress atau pun gila. Sebab menghafal adalah menjaga kalam Allah serta salah satu jalan menjadi kekasih Allah. Sangat tidak mungkin jika kekasih Allah mengalami depresi, stress, gila, hilang ingatan dan sebagainya.

Dalam konteks Total Quality Management, kerjasama dan kesepakatan pihak sekolah dengan orang tua terhadap keefektifan program tahfidz menjadi satu bentuk hubungan yang saling menguatkan dan mutlak tidak dapat terpisahkan. Hal tersebut didasarkan pada beberapa hal diantaranya: pertama, lembaga pendidikan merupakan mata rantai yang menghubungkan pelanggan (customer, klien) dan pemasok (supplier). Sekolah atau lembaga pendidikan apapun dalam realitanya adalah suatu organisasi yang mengendalikan mata rantai para klien. Guru adalah pemasok layanan terhadap peserta didik dan para orang tua, pemerintah merupakan pemasok layanan terhadap guru. Administrator sekolah adalah pemasok layanan kepada guru dan para guru memberikan layanan satu terhadap yang lain. Ada pelanggan internal ialah mereka yang bekerja untuk sekolah dan ada pula pelangan eksternal ialah mereka yang mempunyai tuntutan atau kepentingan layanan dari sekolah.

Kedua, yang merupakan gagasan kunci adalah bahwa semua hubungan antara pelanggan dan pemasok apakah itu internal maupun eksternal ditengahi oleh proses. Guru yang menyelenggarakan kesempatan belajar kepada peserta didik, staf tata usaha yang menyediakan layanan kepentingan atau administrator yang merancang jadwal kegiatan tahunan sekolah, semuanya itu merupakan rangkaian manajemen proses. Mutu atau kualitas diproses melalui perbaikan proses yang diharapkan mampu mendukung hasilhasil yang berbeda dari proses tersebut. Ketiga, orang yang paling dapat melakukan perbaikan proses adalah mereka yang dekat dengan pelanggan dalam proses tersebut. ${ }^{18}$

Peran orang tua dalam mensukseskan program tahfidz di Kejar Paket B Daqu al-Karim juga selaras dengan pernyataan Brofenbrenner dan Morris bahwa atmosfir keluarga akan sangat mempengaruhi perkembangan anak. Sebab tujuan pelibatan orang tua sebagai bentuk menyelaraskan dan menyinergikan pola pendidikan di rumah dan disatuan pendidikan dengan memberikan peningkatan kompetensi orang tua siswa, ${ }^{19}$ dalam berbagai bentuk seperti penguatan pemahaman dan arahan terhadap program yang akan ditempuh oleh anak-anak mereka. Atas dasar itulah, Pemerintah menerbitkan regulasi perihal pelibatan orang tua sebagaimana tertuang dalam Peraturan Menteri Pendidikan Nomor 30 tahun 2017 tentang pelibatan keluarga dalam penyelenggaraan pendidikan yang bertujuan untuk menjalin kemitraan keluarga, satuan pendidikan dan masyarakat untuk membangun ekosistem pendidikan yang menumbuhkan budi pekerti dan budaya prestasi peserta didik.

\footnotetext{
${ }^{18}$ Suto Prabowo, "Total Quality Management (TQM) dalam Pendidikan", Jurnal Sosial Humaniora, (Vol 5 No.1, Juni 2012), hal. 74.

9 Edi dkk, "Pengaruh Keterlibatan Orang Tua dan Pola Asuh terhadap Disiplin Anak", Jurnal Pendidikan Anak Usia Dini, (Vol. 12 Edisi 2, Nopember 2018), hal. 222.
} 
f. Menerapkan Evaluasi Serta Kontrol Program

Proses evaluasi serta kontrol program tahfidz di Kejar Paket B Daqu alKarim dilakukan setiap pekan sekali. Pelaksanaan evaluasi dilakukan dengan melihat alat kontrol terhadap pencapaian hafalan. Evaluasi tidak sebatas dilakukan bagi peserta didik yang mengalami kemunduran dalam menghafal al-Qur'an. Namun peserta didik yang mengalami peningkatan menghafal secara drastis juga dilakukan evaluasi terhadap penyebab peningkatan tersebut. Beberapa penyebab positif tersebut akhirnya dapat di uji cobakan kepada peserta didik yang lain. Sehingga evaluasi dan kontrol program secara ketat sangat berpengaruh terhadap keberhasilan program tahfidz di Kejar Paket B Daqu al-Karim.

Menerapkan evaluasi serta kontrol program tahfidz pada Kejar Paket B Daqu Al-Karim merupakan bagian penting dalam Total Quality Management (TQM). Sebab prinsip manajemen pendidikan berbasis mutu hanya berorientasi pada kepuasan pelanggan (customer satisfaction) yang dilakukan melalui proses perbaikan secara berkesinambungan (continous improvement). ${ }^{20}$

Dari keenam strategi di atas dapat ditegaskan bahwa keberhasilan program tahfidz Kejar Paket B Daqu al-Karim sangat ditentukan oleh visi yang sudah dirumuskan oleh pengelola lembaga serta dukungan dari aspek kepemimpinan, kurikulum, mutu SDM, penguatan kerjasama serta kontrol program. Kesatuan unsur tersebut menciptakan keberhasilan yang tidak dimiliki oleh lembaga pendidikan formal maupun non formal setingkat Sekolah Menengah Pertama. Adapun keberhasilan menghadapi tantangan program sangat ditentukan oleh aspek kepemimpinan serta mutu SDM. Uraian di atas dapat di gambarkan dalam bagan sebagai berikut:

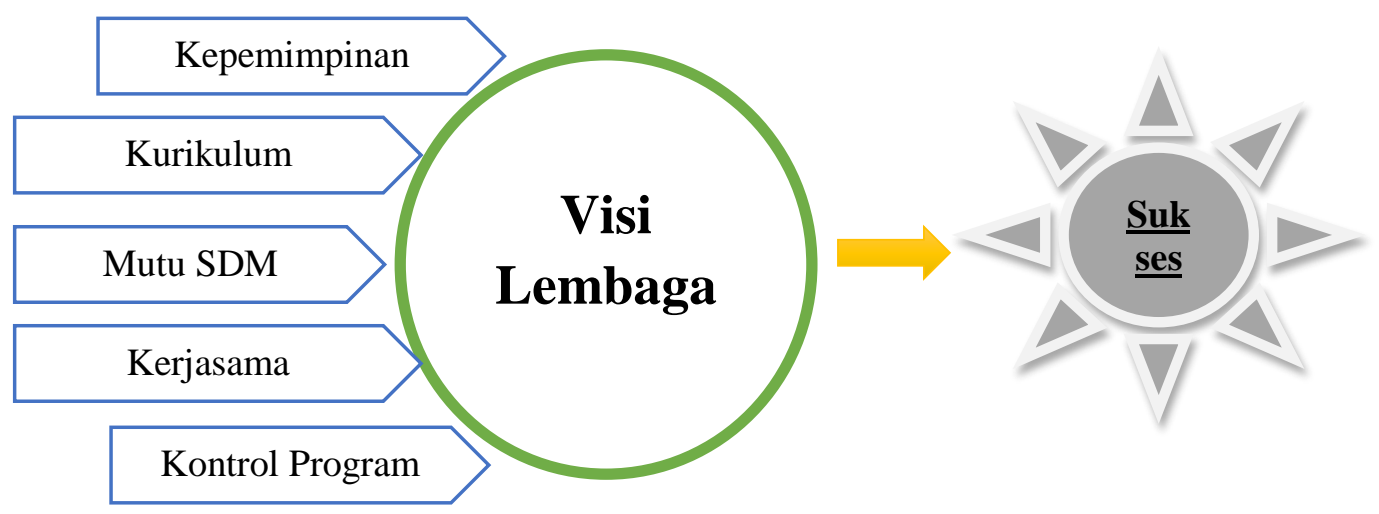

Keberhasilan program tahfidz pada Kejar Paket B Daqu al-Karim terbilang sesuatu yang luar biasa. Perihal tersebut menjadi satu terobosan terbaik sekaligus mengangkat kualitas wajah pendidikan non formal berbentuk Kejar Paket di Indonesia. Sebab progam pendidikan Kejar Paket sejak dahulu dipandang sebagai lembaga pendidikan bagi masyarakat yang tidak memiliki banyak waktu belajar, mengandalkan model belajar mandiri dan penugasan, bahkan sangat jarang ditemui peserta didiknya meraih prestasi yang membanggakan.

Keberhasilan program tahfidz Kejar Paket B Daqu al-Karim selain dinyatakan dalam visi, juga di tentukan oleh beberapa strategi diantaranya:

\footnotetext{
${ }^{20}$ Zulian Yamit, Manajemen Kualitas Produk dan Jasa (Yogyakarta: CV. Adipura, 2001), hal. 181.
} 
lembaga mempersiapkan kekhasan kurikulum berbentuk tahfidz secara aplikatif, selektif dan berkualitas dalam merekrut pendidik dan peserta didik, memperkuat pengembangan metode, meningkatkan mutu kepemimpinan, menciptakan kerjasama serta kesepakatan program, dan menerapkan evaluasi serta kontrol program. Semua itu saling bersinergi satu sama lain serta terevaluasi berdasarkan target capaian yang telah di tentukan.

\section{Daftar Pustaka}

al-Syaibany, Omar Mohammad al-Taumy. (1979). Falsafah Pendidikan Islam, terj. Hasan Langgulung. Jakarta: Bulan Bintang.

Aziz, Safrudin. (2016). Manajemen Mutu Perguruan Tinggi: Koreksi dan Implementasi. Yogyakarta: Gava Media.

Aziz, Safrudin. (2017). Strategi Pembelajaran Aktif Anak Usia Dini: Panduan bagi Guru, Orang Tua, Konselor, dan Praktisi Pendidikan Anak Usia Dini. Yogyakarta: Kalimedia.

Chaidar. (2005 ). "Metodologi Pembelajaran". Makalah Seminar. Medan: Perguruan al-Azhar Medan.

Dakir. (2004). Perencanaan dan Pengembangan Kurikulum. Jakarta: Rineka Cipta.

Departemen Pendidikan Nasional. (2002). Manajemen Peningkatan Mutu Berbasis Sekolah, Konsep Dasar, Buku 1. Jakarta: Direktorat Jenderal Pendidikan Dasar dan Menengah.

Edi dkk. (2018). "Pengaruh Keterlibatan Orang Tua dan Pola Asuh terhadap Disiplin Anak". Jurnal Pendidikan Anak Usia Dini. Vol. 12 Edisi 2, Nopember.

Kamars, M. Dachnel. (2007). "Kebijakan Pendidikan dan Peningkatan Mutu Pendidikan", dalam Membangun Paradigma Pendidikan Islam, ed. Muhmidayeli. Riau: Program Pascasarjana UIN Suska Riau.

Lubis, Halfian. (2008). Pertumbuhan SMA Islam Unggulan di Indonesia: Studi Tentang Strategi Peningkatan Kualitas Pendidikan. Jakarta: Badan Litbang dan Diklat Departemen Agama RI.

M. Saleh, Muntasir. (1985). Pengajaran Terprogram, Teknologi Pendidikan dengan Pengandalan Tutor. Jakarta: Rajawali.

Mulyadi. (2010). Kepemimpinan Kepala Madrasah dalam Mengembangkan Budaya Mutu: Studi Kasus di Madrasah Terpadu MAN 3 Malang, MAN Malang 1 dan MA Hidayatul Mubtadi'in Kota Malang. Jakarta: Bdan Litbang dan Diklat Kementerian Agama RI.

PKBM Darul Qur'an al-Karim. (2017). Dokumen PKBM Darul Qur'an al-Karim Karangtengah Baturraden Banyumas Tahun 2017. Purwokerto: PKBM 
Daqu al-Karim.

Prabowo, Suto. (2012). "Total Quality Management (TQM) dalam Pendidikan". Jurnal Sosial Humaniora. Vol. 5 No.1.

Ramadhan, Yoga Achmad. (2012). "Kesejahteraan Psikologis pada Remaja Santri Penghafal al-Qur'an”. Jurnal Psikologika. 17 (1).

Suprayogo, Imam. (2007). Quo Vadis Madrasah, Gagasan, Aksi dan Solusi Pembangunan Madrasah. Yogyakarta: Hikayat.

Sutrisno. (2015). Pendidikan Islam di Era Peradaban Modern. Jakarta: Prenada Media Group.

Syafaruddin. (2005). Manajemen Lembaga Pendidikan Islam. Jakarta: Ciputat Press.

Yamit, Zulian. (2001). Manajemen Kualitas Produk dan Jasa. Yogyakarta: CV. Adipura.

Yayasan Darul Qur'an al-Karim. (2017). Dokumen Kurikulum Kejar Paket B Daqu al-Karim Karangtengah Baturraden Banyumas Tahun 2017. Purwokerto: tp. 